8 10

$24 \quad{ }^{*}$ Corresponding author: keller@bren.ucsb.edu; (+1)805-893-7548 (tel); (+1)805-893-7612 (fax)

\author{
Adeyemi S. Adeleye ${ }^{a, c}$, Ekene A. Oranu ${ }^{\text {b, c }}$, Mengya Tao ${ }^{a}$, Arturo A. Keller ${ }^{a, c, *}$
}

${ }^{a}$ Bren School of Environmental Science \& Management, University of California, Santa Barbara, CA 93106-5131, USA

${ }^{b}$ College of Letters \& Science, University of California, Santa Barbara, CA 93106-5131, USA

${ }^{c}$ University of California Center for Environmental Implications of Nanotechnology, Santa Barbara, California, USA

3
4 5 列

(7)

8

9

0

1

2

23

\title{
Release and detection of nanosized copper from a commercial antifouling paint
}




\section{Abstract}

26 One major concern with the use of antifouling paints is the release of its biocides (mainly copper

27 and zinc) into natural waters, where they may exhibit toxicity to non-target organisms. While

28 many studies have quantified the release of biocides from antifouling paints, very little is known

29 about the physicochemical state of released copper. For proper risk assessment of antifouling

30 paints, characterization of copper released into water is necessary because the physicochemical

31 state determines the metal's environmental fate and effects. In this study, we monitored release

32 of different fractions of copper (dissolved, nano, and bulk) from a commercial copper-based

33 antifouling paint. Release from painted wood and aluminum mini-bars that were submerged in

34 natural waters was monitored for 180 days. Leachates contained both dissolved and particulate

35 copper species. X-ray diffraction and X-ray photoelectron spectroscopy were used to determine

36 the chemical phase of particles in the leachate. The amount of copper released was strongly

37 dependent on water salinity, painted surface, and paint drying time. The presence of nanosized

$38 \mathrm{Cu}_{2} \mathrm{O}$ particles was confirmed in paint and its leachate using single-particle inductively coupled

39 plasma-mass spectrometry and electron microscopy. Toxicity of paint leachate to a marine

40 phytoplankton was also evaluated.

41

42

43 Keywords

44 Nanoparticles; antifouling paint; copper; environmental fate; toxicity 


\subsection{Introduction}

46 Fouling organisms are undesirable on hulls of ships and boats because they increase drag, and

47 thus reduce fuel economy, and speed, and maneuverability of vessels (Kiil et al., 2001, Valkirs et

48 al., 2003). Inorganic and organic copper $(\mathrm{Cu})$ compounds have long been employed as biocidal

49 agents, and have found use in antifouling (or bottom) paints to prevent colonization of vessel

50 hulls by fouling organisms such as barnacles, tube worms, and algae (Omae, 2003, Turner,

51 2010). One major concern about the use of antifouling paint has to do with passive leaching of

52 biocides into waters during use (Katranitsas et al., 2003, Warnken et al., 2004). Antifouling paint

53 particles may also be released into aquatic systems when spent paint residues are removed during

54 maintenance (Parks et al., 2010). Water and sediment quality surveys in harbors, marinas, and

55 vessel maintenance facilities have found unusually high levels of $\mathrm{Cu}$ (Comber et al., 2002, Hall

56 et al., 1988, Omae, 2003, Parks et al., 2010).

57

58 Several studies have investigated release of $\mathrm{Cu}$ from antifouling paints. For instance, Hall et al.

59 (1988) monitored dissolved $\mathrm{Cu}$ in Chesapeake Bay for 11 months and concluded that

60 recreational boats housed in a marina were most likely responsible for high levels of $\mathrm{Cu}$ detected.

61 Comber et al. (2002) found that $\mathrm{Cu}$ concentration in summer months was twice as much as in

62 winter in an estuary, which was largely attributed to leaching of antifouling paints biocides.

63 Valkirs and coworkers detected dissolved $\mathrm{Cu}$ release rate into San Diego Bay of $8 \mu \mathrm{g} / \mathrm{cm}^{2}$-day

64 from hulls of US Navy vessels and $65 \mu \mathrm{g} / \mathrm{cm}^{2}$-day from painted steel panels (Valkirs et al.,

65 2003). In all these studies (and others), dissolved $\mathrm{Cu}$ was defined as the fraction $<0.45 \mu \mathrm{m}$, as is

66 traditionally done. However, this classification of dissolved $\mathrm{Cu}$ lumps together dissolved ions,

67 nanoparticles (generally defined as particles with at least one dimension between 1 and $100 \mathrm{~nm}$ ) 
and some bulk particles (100 - $450 \mathrm{~nm}$ in size). For proper risk assessment, it is necessary to determine how much of these different fractions of $\mathrm{Cu}$ are leached from antifouling paints since their fate, bioavailability, and toxicity differ considerably (Bielmyer-Fraser et al., 2014, Shi et al., 2011, Siddiqui et al., 2015, Thit et al., 2013, Torres-Duarte et al., 2015).

The goal of this study was to investigate how (1) water salinity, (2) type of surface painted, and (3) consumer behavior (paint drying/curing time) affect the release of different size-fractions of $\mathrm{Cu}$ from a commercial antifouling paint. In addition, we investigated the chemical state of $\mathrm{Cu}$ particles found in water, which were either from undissolved particles or formed via precipitation. High throughput assays were carried out to test the effects of paint leachate on a marine phytoplankton.

\subsection{Materials and Methods}

\subsubsection{Antifouling paint particle characterization}

A commercial self-polishing antifouling paint, Sea Hawk Cukote Biocide Plus Red-3541 (New Nautical Coatings, Clearwater, FL), was used for this study. According to the manufacturer, the antifouling paint has $47.57 \% \mathrm{Cu}_{2} \mathrm{O}$ as the main biocidal ingredient; this information was verified (details below). The composition of the antifouling paint as provided by the manufacturer is shown in Figure A.1 (in Appendix A). Particles in paint were characterized via dynamic light scattering (DLS, Malvern Zetasizer Nano-ZS90), X-ray diffraction (XRD, Bruker D8 Advance), and scanning electron microscopy (SEM, FEI XL30 Sirion equipped with an EDAX APOLLO X probe for energy-dispersive X-ray spectroscopy, EDS). Stock for DLS measurement was prepared by diluting paint in deionized (DI) water (Barnstead NANOpure Diamond) by a factor 
91 of 100, and the emulsion was bath-sonicated (Branson 2510) for $1 \mathrm{~h} .0 .1 \mathrm{~mL}$ of the supernatant

92 was then added to $0.9 \mathrm{~mL}$ DI water and analyzed using the Zetasizer. The amount of $\mathrm{Cu}$ in paint was determined by a combination of ultrasonication (Branson 8800) and acid digestion (Fisher Scientific trace-metal grade $\mathrm{HNO}_{3}$ ) of diluted paint followed by ICP-MS analysis (Agilent 7900, Agilent Technologies, Santa Clara, CA). A graphical summary of the methodology is provided in Appendix A.

\subsubsection{Single Particle Analysis Using ICP-MS}

Single particle inductively coupled plasma-mass spectrometry (sp-ICP-MS) was also employed to further characterize the paint using an Agilent 7900 ICP-MS (e.g. Yamanaka et al., 2015). Method setup and data analyses were done in the Single Nanoparticle Application Module ICPMS MassHunter software (Agilent Technologies). Analyses were performed in time resolved analysis (TRA) mode using an integration time of $0.1 \mathrm{~ms}$ per point with no settling time between measurements. NIST 8012 Au reference material (nominal diameter $=30 \mathrm{~nm}$ ) was employed for determination of nebulization efficiency. The reference material was diluted to $10 \mathrm{ng} / \mathrm{L}$ with $8 \%$ ethanol in DI and sonicated for 5 min to ensure homogeneity. A NIST-traceable $\mathrm{Cu}$ standard (diluted to $1 \mu \mathrm{g} / \mathrm{L}$ ) was used to determine the elemental response factor. The paint was diluted with DI water (while sonicating) such that the $\mathrm{Cu}$ particle concentration was between 10 and 100 $\mathrm{ng} / \mathrm{L}$, and a sample inlet flow of $0.346 \mathrm{~mL} / \mathrm{min}$ was used. Analyte mass fraction was set to 0.89 while particle density was set to $6 \mathrm{~g} / \mathrm{cm}^{3}$.

\subsubsection{Painted surfaces and experimental set-up}

Aluminum sheets ( $\sim 2$ mm thick, 5052 non-heat treatable alloy, Industrial Metal, Ventura, CA) and oak wood (American Wood Moulding, Hanover, MD) were used for this study. Wood was 
115 cut into $3 \times 1 \times 1 \mathrm{~cm}$ mini-bars while aluminum sheet was cut into $3 \times 1 \mathrm{~cm}$ mini-bars. The 116 aluminum and wood mini-bars were pre-treated and painted in accordance with the 117 manufacturer's instruction (see section A.1.0 in the Appendix). Each mini-bar was weighed 118 (Denver Instrument SI-114) after all surface treatments, before and after painting to determine 119 mass of paint applied. Painted mini-bars were allowed to dry for 6 h, $24 \mathrm{~h}$ (minimum time 120 recommended by paint manufacturer), or $7 \mathrm{~d}$, and then submerged in water (20 $\mathrm{mL}$ of freshwater, 121 estuary, or seawater). Estuary water was composed of 50\% freshwater (laboratory tap water;

122 dissolved organic carbon $=1.98 \mathrm{mg}-\mathrm{C} / \mathrm{L}$ ) and 50\% seawater (collected from the Pacific Ocean in 123 Santa Barbara and $0.2 \mu \mathrm{m}$-filtered). Filtration was done to remove potentials interferences such 124 as microorganisms, suspended sediments, and other debris. Characterization of seawater was 125 provided in a previous study (Keller et al., 2010). Submerged coated mini-bars were kept in 126 conditions simulating natural surface waters: cool white fluorescent lights (14:10 light:dark, 80$\left.127100 \mu \mathrm{mol} / \mathrm{m}^{2}-\mathrm{s}\right)$ at $20^{\circ} \mathrm{C}$ with shaking (125 rpm) (Adeleye and Keller, 2014, Miller et al., 2012). 128

\section{$129 \quad$ 2.1.4 Biocide release studies}

130 Release of $\mathrm{Cu}$ from wood and aluminum mini-bars was monitored at time series for $180 \mathrm{~d}$. Each 131 mini-bar was sacrificed after analysis. Full description of the release monitoring is provided in 132 section A.2.0. Briefly, we analyzed for total $\mathrm{Cu}(\mathrm{Cu}$ total $)$, dissolved $\mathrm{Cu}\left(\mathrm{Cu}_{\text {diss }}\right)$, nanosized $\mathrm{Cu}$ 133 (Cunano), and bulk Cu (Cubulk). Cudiss was obtained using Millipore Amicon Ultra-4 3 kDa 134 centrifugal filter tubes (maximum pore size $\sim 2 \mathrm{~nm}$ ) while $\mathrm{Cu}_{\text {nano }}$ was separated using Thermo 135 Scientific Target2 PVDF $0.2 \mu \mathrm{m}$ filters (preliminary analyses showed that nanoparticles in paint 136 were $80-200 \mathrm{~nm}$ in diameter). Morphology and elemental composition of particles in leachates 
137

were studied via transmission electron microscopy (TEM) analyses using a Titan $300 \mathrm{kV}$ FEG TEM/STEM microscope equipped with an Oxford INCA $x$-sight EDS probe.

\subsubsection{Transformation of $\mathrm{Cu}$ biocides in waters}

To study the transformation of $\mathrm{Cu}$ species released from the antifouling paint, $5 \mathrm{~mL}$ of antifouling paint were added to $45 \mathrm{~mL}$ of the three different waters. The individual mixtures were placed on a Dayton-6Z412A Parallel Shaft roller mixer (90 rpm), and analyzed at intervals for up to $180 \mathrm{~d}$. To analyze, the dissolved phase was separated from solids via centrifugation (6000g, 30 min, Sorvall RC 5B Plus). The solid phase was then dried in a Baxter vacuum dryer and analyzed via X-ray photoelectron spectroscopy (XPS) and XRD to determine the chemical states of particulate $\mathrm{Cu}$. XPS analyses were carried out with a Kratos Axis Ultra DLD spectrometer using a monochromatic Al Ka source at $225 \mathrm{~W}$. Samples were spread over doublesided tape, and an analysis area of $300 \mu \mathrm{m} \times 700 \mu \mathrm{m}$ was used. Instrument base pressure was below $10^{-8}$ Torr. All survey spectra were collected at $160 \mathrm{eV}$ pass energy, $0.5 \mathrm{eV}$ step, and 150 ms dwell time per sample. High-resolution spectra were collected using $20 \mathrm{eV}$ pass energy, 0.05 $\mathrm{eV}$ step, and $300 \mathrm{~ms}$ dwell time. Repeated analyses done using the same sample area and similar parameters showed reduction from $\mathrm{Cu}(\mathrm{II})$ to $\mathrm{Cu}(\mathrm{I})$ so the high resolution spectra for $\mathrm{Cu} 2 \mathrm{p}$ were collected differently. $\mathrm{Cu} 2 \mathrm{p}$ high resolution peaks were collected from areas that were not previously exposed to X-rays and the acquisition time was limited to $60 \mathrm{~s}$ using $40 \mathrm{eV}$ pass energy, $0.1 \mathrm{eV}$ steps, and $400 \mathrm{~ms}$ dwell time. We confirmed from preliminary analyses that $\mathrm{Cu}$ $2 p_{3 / 2}$ peak areas are twice those of $\mathrm{Cu} 2 \mathrm{p}_{1 / 2}$ peaks, and that all the peaks used to determine the speciation of $\mathrm{Cu}$ in the $\mathrm{Cu} 2 \mathrm{p}_{3 / 2}$ and $\mathrm{Cu} 2 \mathrm{p}_{1 / 2}$ are equally distant apart. As such the data used for this manuscript was only collected for $\mathrm{Cu}_{2} \mathrm{p}_{3 / 2}$ peaks $(940-928 \mathrm{eV})$ to minimize sample exposure 
to X-rays. We confirmed that our samples were not altered by these acquisition conditions. The Kratos charge neutralizer system was used for all analyses with charge neutralization being monitored using the $\mathrm{C} 1 \mathrm{~s}$ signal for adventitious carbon. Spectra were analyzed using CasaXPS software (Fairley and Carrick, 2005) (version 2.3.16).

\subsubsection{Effect of paint leachates on marine phytoplankton}

Toxicity of paint leachate in marine systems was evaluated using algal growth-inhibition assays. An axenic culture of Isochrysis galbana was obtained from the Provasoli-Guillard National Center for Marine Algae and Microbiota (Bigelow Laboratory for Ocean Sciences, East Boothbay, ME), and was maintained as described previously (Miller et al., 2012) (summarized in section A.3.0). To provide inoculant for experiments, the phytoplankton was incubated in 150 $\mathrm{mL}$ for 6 days. For the experiments, the cultures were inoculated at an initial density of $2 \times 10^{4}$ cells $/ \mathrm{mL}$ in a black 96-well microplate with clear-bottom (Corning Inc., Kennebunk, ME) containing $200 \mu \mathrm{L}$ of exposure solution. Incubation was done under cool white fluorescent lights $\left(15,000\right.$ lux, $14: 10$ light:dark) at $20^{\circ} \mathrm{C}$. Light intensity was monitored using a Traceable ${ }^{\mathrm{TM}}$ DualRange Light Meter (Fisher Scientific). Cultures were mixed constantly at $400 \mathrm{rpm}$ with a Talboys 1000MP microplate shaker (orbit $=3 \mathrm{~mm}$ ). Cell densities were monitored every $24 \mathrm{~h}$ for $5 \mathrm{~d}$ by measuring fluorescence (BioTek Synergy H1) at excitation wavelength of $485 \mathrm{~nm}$ and emission wavelength of $685 \mathrm{~nm}$. Only the seawater leachates obtained after $180 \mathrm{~d}$ were tested, and were diluted by a factor of 10 . Five replicates were used for each condition. The average specific growth rate of the algae for the duration of exposure was calculated according to the following logistic equation: 


$$
\mu_{i-j}=\frac{\ln X_{i}-\ln X_{j}}{t_{i}-t_{j}}\left(d a y^{-1}\right)
$$

184 where $\mu_{i-j}$ is the average specific growth rate from time $i$ to $j ; X_{i}$ and $X_{j}$ are the relative fluorescence at time $i$ and $j$, respectively; and $t_{i}$ and $t_{j}$ are the initial time of exposure and final time of exposure, respectively. Percentage inhibition of growth was calculated as:

$$
I=\frac{\mu_{C}-\mu_{T}}{\mu_{C}} \times 100
$$

where $I$ is the percent inhibition in average specific growth rate; $\mu_{C}$ is the average specific growth rate in the control group, and $\mu_{T}$ is the average specific growth rate for the treatment.

\subsection{Result and Discussions}

\subsubsection{Characterization of paint particles}

Preliminary analysis of antifouling paint particles was done via DLS analysis of paint emulsion to determine if colloids, and specifically nanomaterials, were present. DLS data was collected every $30 \mathrm{~s}$ for $12 \mathrm{~h}$ so as to obtain representative data. As shown in Figure A.2, the antifouling paint contained nanosized particles with a modal diameter of $\sim 220 \mathrm{~nm}$. In general the hydrodynamic diameter of nanomaterials is much greater than their primary particle size due to aggregation in aqueous phase, and the presence of water films around the particles (Adeleye et al., 2014). Therefore, the average primary particle size of the nanomaterials in the antifouling paint is probably less than $220 \mathrm{~nm}$. Particles with hydrodynamic diameters ranging from $44 \mathrm{~nm}$ to $5 \mu \mathrm{m}$ were detected by DLS analyses (Figure A.2a). This agrees very well with (1) SEM analyses, shown in Figure 1, where both nano- and micron-sized $\mathrm{Cu}$ particles were detected and confirmed via EDS hypermapping; and (2) sp-ICP-MS analyses, presented in Figure 2, which 
shows that the most abundant particle size was $44 \mathrm{~nm}$. As can be seen in the size distribution of the $\mathrm{Cu}$ particles in paint (Figure 2), most of the particles analyzed were between 40 and $200 \mathrm{~nm}$,

207 although some low intensity peaks were observed up to $460 \mathrm{~nm}$. The micron-sized particles

208 shown via SEM analyses to be present in paint probably settled out of solution and were not 209 detected during sp-ICP-MS analyses.
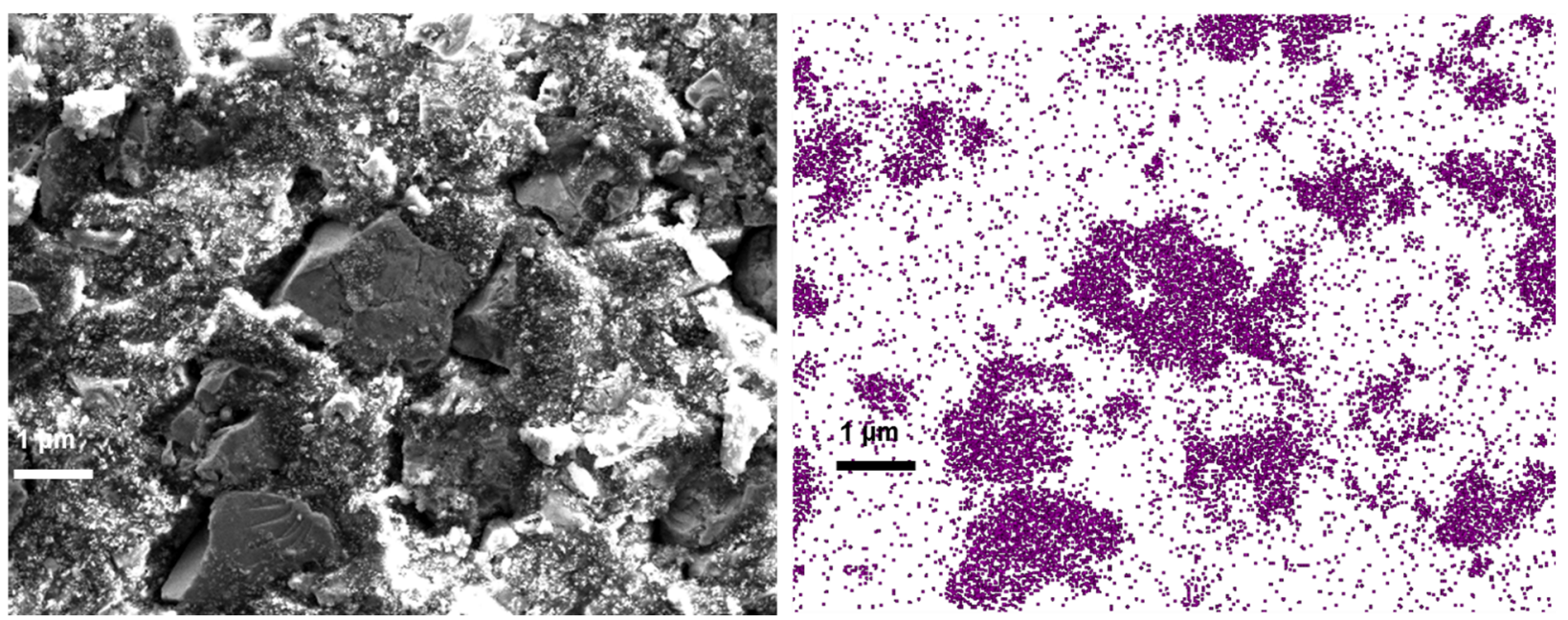

213 Figure 1. Scanning electron micrograph of dried paint (left) and hypermap of copper in the

214 sample (right) obtained from energy-dispersive X-ray spectroscopy (EDS) analysis

$217 \mathrm{XRD}$ analysis confirmed that the form of $\mathrm{Cu}$ in the antifouling paint is mainly cubic synthetic

218 cuprite or $\mathrm{Cu}_{2} \mathrm{O}$ (Figure A.3), which agrees well with information from the manufacturer. ICP-

$219 \mathrm{MS}$ analyses revealed that $\mathrm{Cu}$ concentration was $55.5 \%$ by mass. This is somewhat higher than

220 the $\mathrm{Cu}$ content reported by the manufacturer (48\%), and was used for all the calculations in this

221 study. 


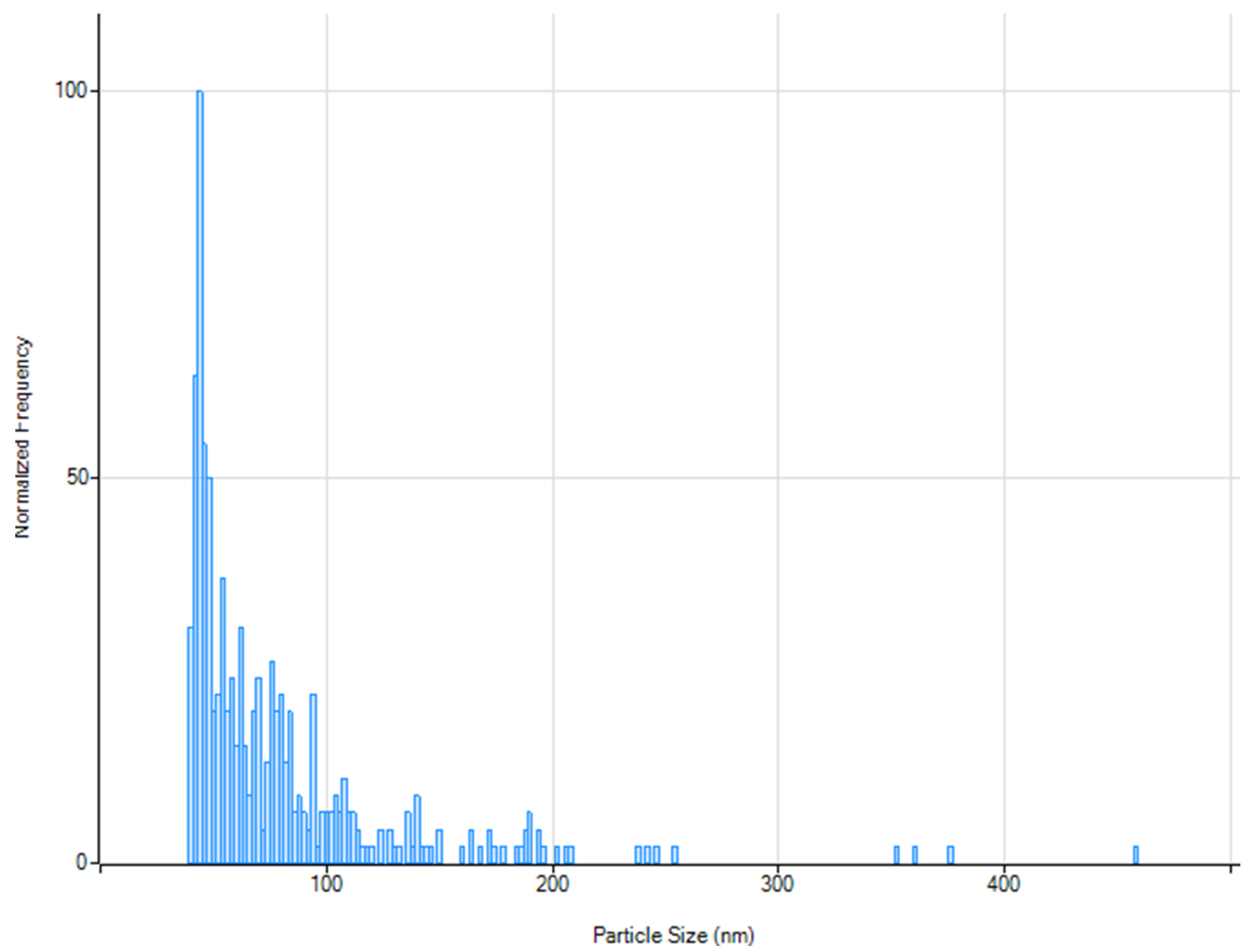

223 Figure 2. Particle size distribution of $\mathrm{Cu}_{2} \mathrm{O}(\mathrm{as} \mathrm{Cu})$ present in antifouling paint obtained from 224 single particle-ICP-MS

225

\subsubsection{Release of $\mathrm{Cu}$ from paint}

227 3.1.2.1 Effect of painted material on Cu release

228 To quantify release of biocide from painted surfaces, we analyzed for $\mathrm{Cu}$ species the waters in 229 which the mini-bars were submerged. The data presented and discussed in this section were 230 derived from mini-bars dried for $24 \mathrm{~h}$, and exposed in seawater; the effects of drying time and 231 salinity are discussed later. The amount of $\mathrm{Cu}$ release increased over time: $\mathrm{Cu}$ concentration (in $232 \mathrm{mg} / \mathrm{L}$ ) increased from 0.01 to 41.5 and 1.47 to 625.7 between Days 0 and 180 in aluminum and 
233 wood mini-bars, respectively (Figure 2 and A.4). In general, the mass of $\mathrm{Cu}$ found in leachates of

234 wood mini-bar treatments was an order of magnitude (or more) higher than in corresponding

235 aluminum treatments. This is partly due to the presence of higher amounts of antifouling paint on

236 wood mini-bars and much higher release rate of antifouling paint (biocide) from wood. While

237 their length and width were similar, wood mini-bars were $80 \%$ thicker than aluminum mini-bars.

238 In addition, wood mini-bars were covered with three coats of the antifouling paint versus two

239 coats for aluminum (the minimum amount of coats suggested for the different surfaces by the

240 manufacturer). To take into account the effect of higher amounts of antifouling paint on wood

241 mini-bars (due to larger size and additional coating), the mass of $\mathrm{Cu}$ released from each mini-bar

242 was normalized by the mass of $\mathrm{Cu}$ in their individual coatings. We found that maximum $\mathrm{Cu}$

243 released over $180 \mathrm{~d}$ was $0.21 \%$ from aluminum and $1.76 \%$ from wood. This result confirms that

244 considerably more $\mathrm{Cu}$ was released from painted wood than aluminum surfaces.

245

246 Mass flux ( $\mathrm{F}_{\text {mass }}$ ) of $\mathrm{Cu}$ released from the mini-bars was derived by normalizing the mass of paint

247 released over $180 \mathrm{~d}$ by the surface area of the mini-bars. Fmass was $3.01 \mu \mathrm{g} / \mathrm{cm}^{2}$-day for

248 aluminum mini-bars and $26.4 \mu \mathrm{g} / \mathrm{cm}^{2}$-day for wood mini-bars in seawater. Release of biocides

249 from surfaces painted with antifouling paints is controlled by biocide chemistry, hydrodynamics,

250 temperature, salinity, pH, microbial biofilm, (Kiil et al., 2001, Kiil et al., 2002, Valkirs et al.,

2512003 ) and as shown here, painted material. When the mini-bars were removed from waters for

252 sampling, we observed slight swelling of wood mini-bars. This suggests that wood mini-bars

253 imbibed some water. In addition to swelling, we also observed cracks and peels on the

254 antifouling paint coats of wood mini-bars (but not in aluminum mini-bars) that were submerged

255 for a long time. This led us to believe that in addition to the leaching of biocides into water from 
256 antifouling paints, $\mathrm{Cu}$ was also released due to water percolating into the wood and the poor

257 dimensional stability of wood in water, which is probably responsible for higher leachate

258 amounts. It should be noted that such material instability may be less pronounced in real wooden

259 hulls, which are typically made with much larger and thicker woods. The resins in antifouling

260 paints are porous, allowing some inflow of water. Additionally some of the organic solvent in

261 antifouling paints vaporized when the painted mini-bars were dried/cured and additional solvents

262 may have been released into water when submerged, thereby reducing the hydrophobicity of the

263 paint and allowing for penetration of water.

264

265

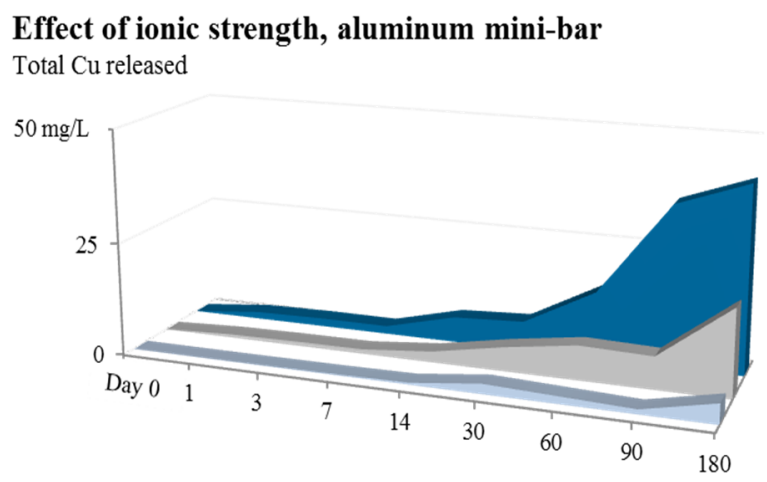

266

267

268

269

270

271 Unlike wood, the layers of epoxy primers on aluminum mini-bars (see section A.1.0) effectively

272 excluded water, and release was assumed to be due only to regular biocide leaching, as would be

273

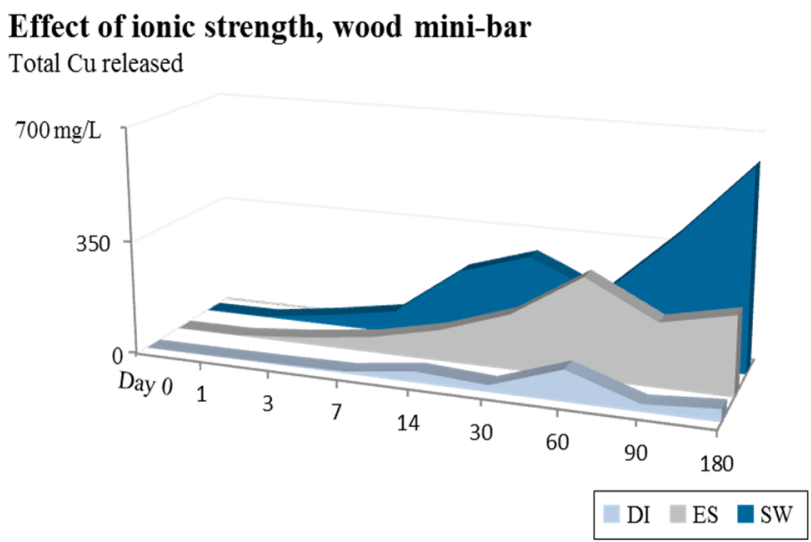

Figure 3. Total $\mathrm{Cu}$ released from aluminum and wood mini-bars over $180 \mathrm{~d}$. Freshwater $=\mathrm{DI}$, estuary $=\mathrm{ES}$, and seawater $=\mathrm{SW}$. Paint drying time $=24 \mathrm{~h}$ expected in any stable hull material. Although wooden hulls are becoming less popular, many 
274 sailboats and older ships have wooden hulls. As shown in this study, these types of hulls have the 275 tendency to release a higher amount of biocides into surface waters than aluminum hulls. Other 276 materials such as fiberglass and steel are often coated with impermeable epoxy primers prior to

277 antifouling paint application, and are thus expected to behave similar to aluminum mini-bars 278 used in this study. In fact, the release rate we found in aluminum mini-bars $\left(3.01 \mu \mathrm{g} / \mathrm{cm}^{2}\right.$-day) is 279 very similar to the mean in-situ release rate of $\mathrm{Cu}$ from the hull of US Naval vessels measured in 280 San Diego Bay $\left(3.8 \mu \mathrm{g} / \mathrm{cm}^{2}\right.$-day) (Valkirs et al., 2003).

\subsubsection{Effect of salinity on Cu release}

283 The amount of $\mathrm{Cu}$ detected in the aqueous phase over $180 \mathrm{~d}$ increased with increasing salinity 284 (Figure 2 and A.4). Cutotal from aluminum mini-bars (dried for $24 \mathrm{~h}$ ) on day 180 was 4.47, 19.5, 285 and $41.5 \mathrm{mg} / \mathrm{L}$ in DI, estuary, and seawater, respectively. Similarly, Cutotal from wood mini-bars 286 at the same time period was 38.2, 243, and $626 \mathrm{mg} / \mathrm{L}$ in DI, estuary, and seawater, respectively. 287 In addition to effects of salinity on the amount of $\mathrm{Cu}$ leached out of the mini-bars, a clear effect 288 of salinity on the size fractions of released $\mathrm{Cu}$ was also observed. For instance, more than $90 \%$ of

$289 \mathrm{Cu}_{\text {total }}$ detected within $2 \mathrm{~h}$ of exposing aluminum mini-bars to seawater was ionic $\mathrm{Cu}\left(\mathrm{Cu}_{\text {diss }}\right)$;

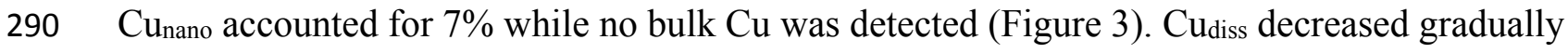
291 with time, but remained the predominant fraction for the first 7 days. Conversely, Cubulk 292 increased steadily with time and was approximately equal to $\mathrm{Cu}$ diss on day 14 after which it 293 became the dominant fraction. The range of $\mathrm{Cu}_{\text {nano }}$ detected in seawater over $180 \mathrm{~d}$ was $1.5-$ $2947460 \mu \mathrm{g} / \mathrm{L}$ or $5-21 \%$ of $\mathrm{Cu}_{\text {total }}$. 
Size fractions of $\mathrm{Cu}$ released into freshwater Fraction of $\mathrm{Cu}$ released

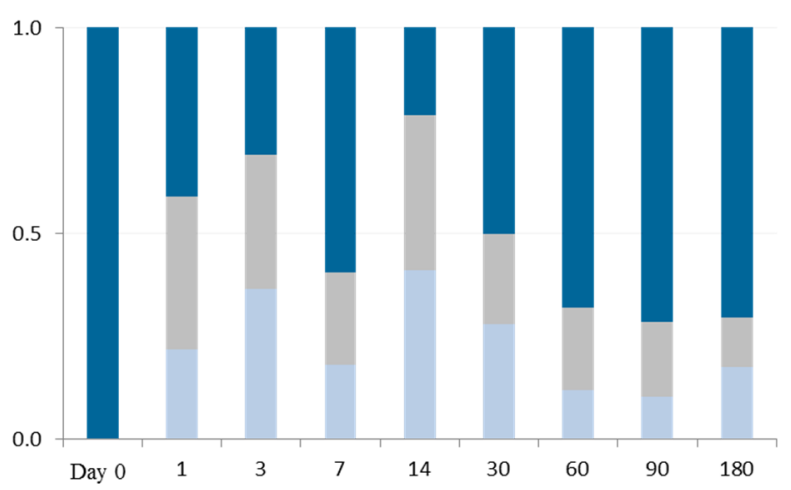

Size fractions of $\mathrm{Cu}$ released into seawater Fraction of $\mathrm{Cu}$ released

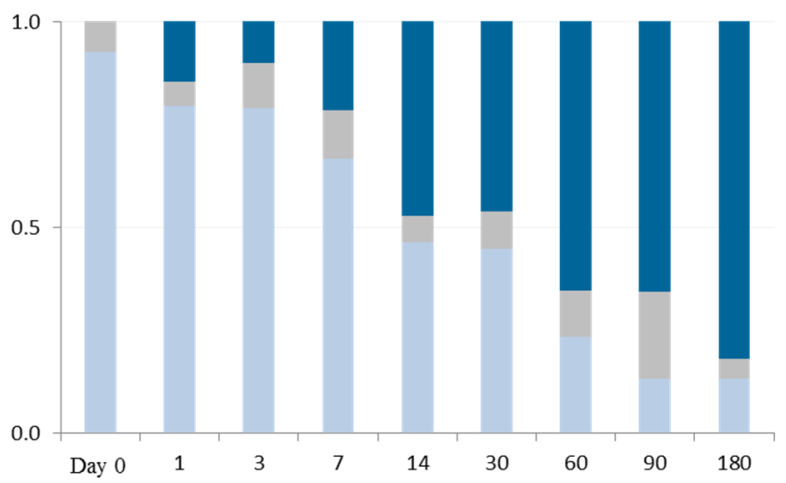

Dissolved ${ }_{\text {Nano }}$ Bulk

In contrast to our observations in seawater treatments, $\mathrm{Cu}_{\text {diss }}$ was either completely absent or only present at low levels within the first 7 days of exposing painted mini-bars to freshwater (Figure 3). The fraction of Cubulk over the 180-d experiment period was $21-100 \%$, making it the most

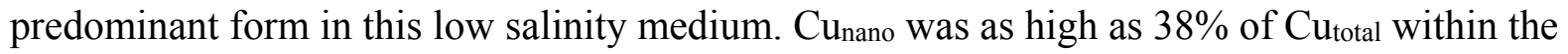
first two weeks, after which it decreased steadily to $12 \%$. The actual amount of $\mathrm{Cu}_{\text {nano }}$ determined in freshwater during the experiment was $0-540 \mu \mathrm{g} / \mathrm{L}$. There was no clear pattern in estuarine conditions (Figure A.5) since it is a complex balance between freshwater and marine processes, but $\mathrm{Cu}$ diss was the predominant $\mathrm{Cu}$ fraction, accounting for $28-88 \%$ of $\mathrm{Cu}$ total over $180 \mathrm{~d}$. Unlike the seawater treatments however, Cubulk did not become dominant throughout the 180-d period; and the fraction of $\mathrm{Cu}_{\text {nano }}$ was higher than in seawater but less than in freshwater (up to $32 \%$ ). 
314 The dissolution of $\mathrm{Cu}_{2} \mathrm{O}$ in natural waters is largely controlled by the ions present, especially

315 chloride $\left(\mathrm{Cl}^{-}\right)$ions as shown in Eq. 3 (Ferry and Carritt, 1946, Singh and Turner, 2009). It is

316 noteworthy that dissolution of $\mathrm{Cu}_{2} \mathrm{O}$ may still occur when $\mathrm{Cl}^{-}$is unavailable. In the absence of

$317 \mathrm{Cl}^{-}$, protons $\left(\mathrm{H}^{+}\right)$may react with the oxygen $(\mathrm{O})$ atom in $\mathrm{Cu}_{2} \mathrm{O}$ to produce cuprous ions $\left(\mathrm{Cu}^{+}\right)$.

318 However, the reaction rate is very slow at typical natural water $\mathrm{pH}$ range $(\sim \mathrm{pH} 6-8)$ (Ferry and

319 Carritt, 1946). When antifouling paint-coated boat hulls are in water, $\mathrm{Cu}_{2} \mathrm{O}$ particles in the paint 320 matrix undergo a complexation reaction with $\mathrm{Cl}^{-}$, releasing complexed $\mathrm{Cu}^{+}$into water (Eq. 3 and 321 4) (Ferry and Carritt, 1946, Kiil et al., 2001, Singh and Turner, 2009). In oxygenated water, $\mathrm{Cu}^{+}$ 322 may be rapidly converted to cupric ion $\left(\mathrm{Cu}^{2+}\right)$ (Adeleye et al., 2014, Kiil et al., 2001, Valkirs et 323 al., 2003).

$$
0.5 \mathrm{Cu}_{2} \mathrm{O}+\mathrm{H}^{+}+2 \mathrm{Cl}^{-} \leftrightarrow \mathrm{CuCl}_{2}^{-}+0.5 \mathrm{H}_{2} \mathrm{O}
$$

$$
\mathrm{CuCl}_{2}^{-}+\mathrm{Cl}^{-} \leftrightarrow \mathrm{CuCl}_{3}^{2-}
$$

This explains the abundance of $\mathrm{Cu}_{\text {diss }}$ in seawater $\left(\mathrm{Cl}^{-} \approx 19.3 \mathrm{~g} / \mathrm{L}\right.$ (Keller et al., 2010)) and estuary $\left(\mathrm{Cl}^{-} \approx 9.70 \mathrm{~g} / \mathrm{L}\right.$, based on dilution of seawater), compared to freshwater, $\left(\mathrm{Cl}^{-}=0.06 \mathrm{~g} / \mathrm{L}\right.$; determined by a $\mathrm{Hg}\left(\mathrm{NO}_{3}\right)_{2}$ titration method, Hanna Instruments) (Conway et al., 2015). Although the fraction of $\mathrm{Cu}_{\text {diss }}$ decreased over time in seawater, the actual concentration of $\mathrm{Cu}_{\text {diss }}$ increased 332 from $18.4 \mu \mathrm{g} / \mathrm{L}$ at the start of the experiment to $555 \mu \mathrm{g} / \mathrm{L}$ after $180 \mathrm{~d}$. Increasing amounts of 333 Cubulk over time in seawater is probably due to the formation of $\mathrm{Cu}^{2+}$ solids (e.g. $\mathrm{CuO}, \mathrm{Cu}(\mathrm{OH})_{2}$ or $\mathrm{CuCl}_{2}$, etc. as explained in section 3.1.3) from oxidation of $\mathrm{Cu}^{+}$in bulk seawater and estuary. 335 A low amount of $\mathrm{Cl}^{-}$in freshwater explains the relatively low $\mathrm{Cu}_{\text {diss }}$ and overall leaching rate of $336 \mathrm{Cu}$ from the antifouling paint in that condition (Figures 2 and A.4). In fact, our results show a 
337 clear linear relationship between $\mathrm{Cl}^{-}$concentration and $\mathrm{Cu}$ release rate $\left(\mathrm{R}^{2}=0.999\right.$ in wood and

3380.981 in aluminum, Figure A.6).

340 In general, dissolved organic carbon (DOC) enhances dissolution of $\mathrm{Cu}$ in natural waters via 341 complexation (Adeleye et al., 2014, Conway et al., 2015). In this study however, complexation

342 of $\mathrm{Cu}$ by DOC is minimal compared to that of $\mathrm{Cl}^{-}$based on the amounts of both complexing 343 agents present. The DOC in the tap water used in this study $(1.98 \mathrm{mg}-\mathrm{C} / \mathrm{L})$ is thrice as much as 344 that in the seawater $(0.65 \mathrm{mg}-\mathrm{C} / \mathrm{L})$. As such, increased dissolution of $\mathrm{Cu}$ in seawater is mainly 345 due to Cl- complexation and not DOC complexation.

346

347 3.1.2.3 Effect of drying time on Cu release

348 In addition to mini-bars coated with the antifouling paint and dried for $24 \mathrm{~h}$ (as recommended by 349 the paint manufacturer), additional mini-bars were coated with the antifouling paint and dried for $3503 \mathrm{~h}$ (short drying time) or $7 \mathrm{~d}$ (long drying time) in other to see how consumer behavior may 351 influence leaching of $\mathrm{Cu}$ from antifouling paints. As shown in Figure 3, mass of $\mathrm{Cu}$ released over $352180 \mathrm{~d}$ increased with paint drying time, which is counterintuitive. 
Effect of paint drying time, Aluminum

Total $\mathrm{Cu}$ leached

$2.5 \mathrm{mg}$

355

356

357

358

359

360

361

362

363

364

365

366 369 time, particularly if it is wooden.

370

371 difference in y-axis scales.

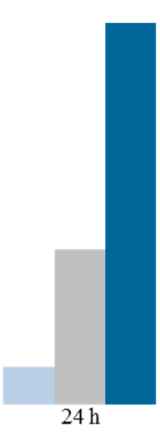

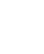

1

$367 \mathrm{Cu}$ from wood mini-bars is partly due to imbibition of water by the mini-bars. This suggests that 368 a painted boat should be placed back in water shortly after the manufacturer's specified curing

372 by consumer behavior. As shown here, allowing painted hulls to dry for much longer than

Effect of paint drying time, Wood

Total $\mathrm{Cu}$ leached

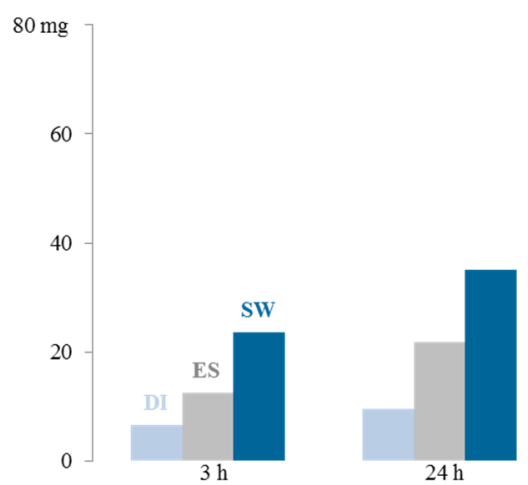

Figure 5. Effect of paint drying time (3h, $24 \mathrm{~h}$, and $7 \mathrm{~d}$ ) on mass of $\mathrm{Cu}$ released from aluminum and wood mini-bars into freshwater (DI), estuary (ES), and seawater (SW) over $180 \mathrm{~d}$. Note the
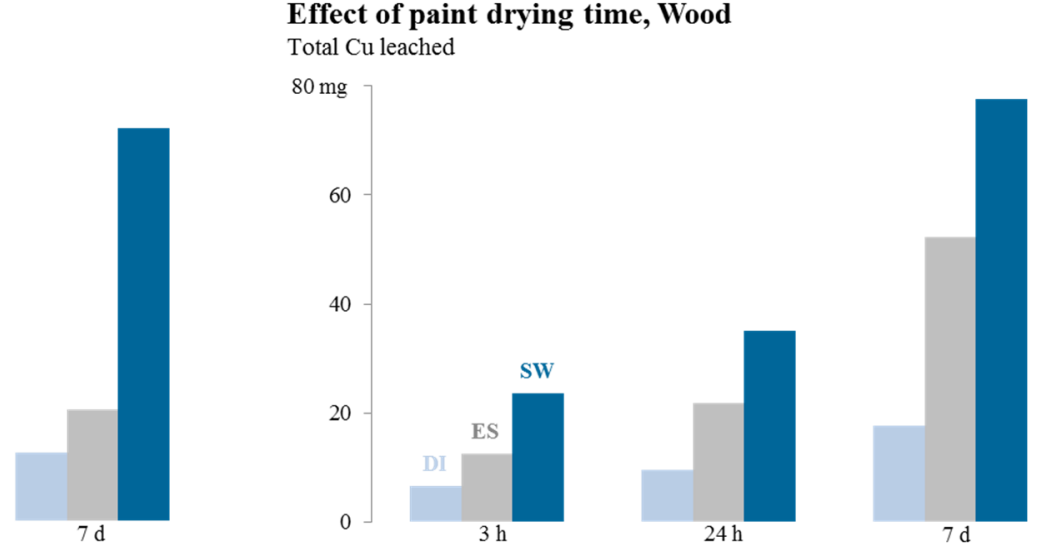
and wood mini-bars into freshwater (DI), estury (ES), and seawater (SW) over $180 \mathrm{~d}$. Note the

In general, as oil-based paints dry out (cure) many of the organics in the paint volatilize while the polymers, pigments and other additives harden. These processes increase the porosity of the paint matrix, while somewhat also reducing its hydrophobicity. As a result, more water is able to percolate into the paint matrix with increased drying time, leading to increased $\mathrm{Cu}_{2} \mathrm{O}$ dissolution and leaching. The effect of drying time was stronger in wood mini-bars compared to aluminum mini-bars (Figure 4). This is in agreement with our earlier observation that increased leaching of

In general, our results demonstrate that release of biocides from antifouling paints is influenced 
373 recommended by the antifouling paint manufacturer may actually lead to additional release of

374 biocides into water. In addition, the type of surface on which antifouling coatings are applied

375 influences leaching of biocides, as materials with poor dimensional stability such as wood may

376 lead to additional leaching.

377

\section{$378 \quad$ 3.1.3 Transformation of released $\mathrm{Cu}$}

379 XRD and XPS analyses were used to characterize the particulate materials in leachates of paint

380 in order to better understand how $\mathrm{Cu}_{2} \mathrm{O}$ particles in the antifouling paint are transformed over

381 time in natural waters. A combination of these two X-ray techniques is extremely useful for

382 probing transformation at particle surface since XPS determines surface composition to a depth

383 of 8-12 nm while XRD can penetrate up to hundreds of microns into particles.

384

385 The dominant peaks detected in XRD diffractograms in all three waters (up to $180 \mathrm{~d}$ ) were 386 assigned to $\mathrm{Cu}_{2} \mathrm{O}$ (Figure 5A; for $2 \mathrm{O}$ see Figure A.7), although major peaks for $\mathrm{ZnO}$ and $\mathrm{Fe}_{2} \mathrm{O}_{3}$

387 were also detected (Figure A.7). Other chemical states of $\mathrm{Cu}$ observed in the XRD data were

$388 \mathrm{CuCl}(2 \Theta \approx 29.0)$, and $\mathrm{CuCl}_{2}(2 \Theta \approx 45.9)$, which were only detected in seawater samples (Figure

389 5B). Also, a peak for $\mathrm{CuCl}_{2}$ was only observed in Day 180 samples. These results suggest that

390 the environmental transformation of $\mathrm{Cu}_{2} \mathrm{O}$ embedded in the antifouling paint used in this study is

391 quite slow_ - taking weeks to months. In addition, precipitation of dissolved $\mathrm{Cu}$ ions in marine

392 systems is driven by $\mathrm{Cl}^{-}$, which is also mainly responsible for $\mathrm{Cu}$ dissolution, as discussed

393 earlier. 
395 For XPS analyses, all of the peaks used to model different $\mathrm{Cu}$ species have full width at half 396 maximum (FWHM) values that are $+/-0.3 \mathrm{eV}$ (instead of the more conventional $+/-0.2 \mathrm{eV}$ ) due

397 to the complexity of the paint matrix and the low resolution of the data that was necessitated by

$398 \mathrm{Cu}(\mathrm{II})$ alteration by X-rays. XPS survey scans of the particulate paint materials showed an 399 abundance of $\mathrm{C}$ and $\mathrm{O}$ atoms (Figure A.8), which are probably from the polymers, hydrocarbons, 400 and resins in the paint matrix (Figure A.1). In addition, zinc, silicon, and magnesium were 401 detected, which were also listed as ingredients by the manufacturer. Although about half of the 402 paint mass is $\mathrm{Cu}$, the amount of $\mathrm{Cu}$ detected by XPS was relatively low. This is mainly because $403 \mathrm{Cu}$ particles in self-polishing antifouling paints are typically encapsulated in resins within the 404 paint matrix. Encapsulation is done to control the release/transformation of $\mathrm{Cu}$, and was 405 visualized in this study via SEM analysis (Figure 1).

406

407
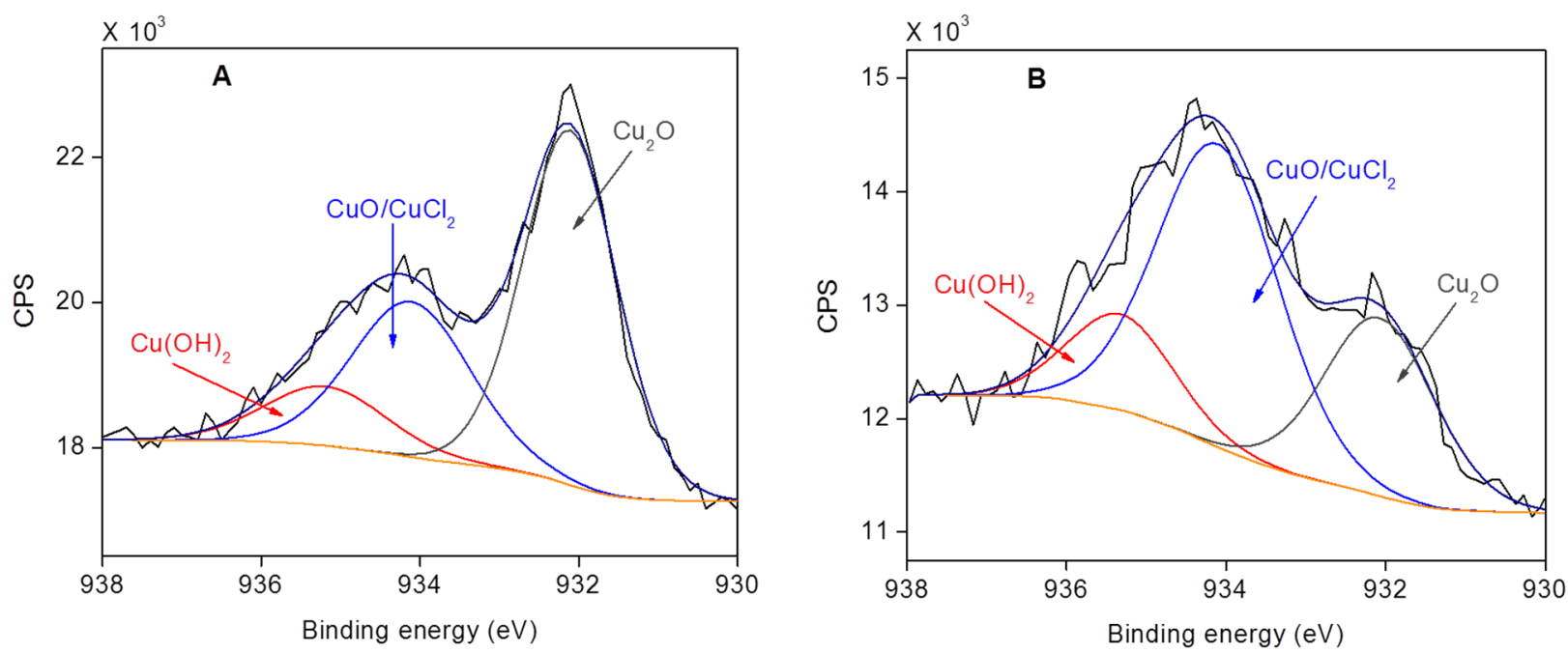

408

Figure 6. High resolution $\mathrm{Cu} 2 \mathrm{p}_{3 / 2}$ spectra of solid fractions of antifouling paint obtained after $180 \mathrm{~d}$ of immersion in (A) freshwater and (B) seawater showing the difference in the abundance 
411 of $\mathrm{Cu}(\mathrm{I})$ and $\mathrm{Cu}(\mathrm{II})$ species. Sample acquisition time was minimized to prevent sample alteration 412 by X-ray

415 High resolution XPS analyses of samples obtained after $180 \mathrm{~d}$ are shown in Figures 5 and A.9.

416 The abundance of $\mathrm{Cu}(\mathrm{II})$ species was much higher than $\mathrm{Cu}(\mathrm{I})$ in the samples exposed to marine 417 conditions while $\mathrm{Cu}(\mathrm{I})$ was more abundant in freshwater samples, showing the effect of salinity 418 in the transformation of $\mathrm{Cu}_{2} \mathrm{O}$ in antifouling paints. Deconvolution of the high resolution scans 419 of $\mathrm{Cu} 2 \mathrm{p}_{3 / 2}$ peaks (Figures $5 \mathrm{~b}$ and $\mathrm{A} .9$ ) revealed that $\mathrm{Cu}$ was present as $\mathrm{Cu}_{2} \mathrm{O}$ in samples obtained 420 from all three media $(\mathrm{BE} \approx 932.2 \mathrm{eV})$ (Moulder et al., 1995), which agrees with the XRD 421 analyses. The peaks found around $934.1 \mathrm{eV}$ in samples from all three waters may be assigned to $422 \mathrm{CuO}, \mathrm{CuCO}_{3}(\mathrm{OH})_{2}$, and $\mathrm{CuCl}_{2}$ (Dzhurinskii et al., 1975, Moulder et al., 1995, Vasquez, 1998). 423 Since we did not detect the C 1s peak for carbonate (typically at $289.1 \mathrm{eV}$ (Vasquez, 1998), 424 Figure A.10), we assigned the peak to $\mathrm{CuO}$ and $\mathrm{CuCl}_{2}$, which also agrees with $\mathrm{XRD}$ analysis. 425 The peak at $935.2 \mathrm{eV}$ was assigned to $\mathrm{Cu}(\mathrm{OH})_{2}$ (Dake et al., 2000, Moulder et al., 1995). While 426 the fraction of $\mathrm{Cu}_{2} \mathrm{O}$ in the $\mathrm{Cu} 2 \mathrm{p}_{3 / 2}$ peaks was relatively constant over time in the samples 427 obtained from freshwater, it decreased progressively over time in the marine water-exposed 428 samples. For instance, $\mathrm{Cu}_{2} \mathrm{O}$ fraction was $65 \%, 47 \%$, and $29 \%$ in samples exposed to seawater 429 for $2 \mathrm{~h}, 30 \mathrm{~d}$, and $180 \mathrm{~d}$, respectively (data not shown). These $\mathrm{X}$-ray data show that $\mathrm{Cu}_{2} \mathrm{O}$ 430 particles in the antifouling paint are progressively transformed into $\mathrm{CuO}$ or $\mathrm{CuCl}_{2}$ while 431 dissolved $\mathrm{Cu}$ is precipitated as $\mathrm{Cu}(\mathrm{OH})_{2}$ especially in marine waters. This agrees well with our 432 finding of dominance of bulk $\mathrm{Cu}$ - over time -in the seawater treatments (Figure 3). In a previous 433 study using MINTEQ modeling, copper nanoparticles were predicted to oxidize, at equilibrium, 
434 mainly to $\mathrm{CuO}$ and $\mathrm{Cu}_{2} \mathrm{Cl}(\mathrm{OH})_{3}$ in marine systems (Conway et al., 2015). It should be noted that $435 \mathrm{CuO}$ can also dissolve to an extent over time, leading to more complexation and precipitation 436 (Adeleye et al., 2014, Conway et al., 2015).

437
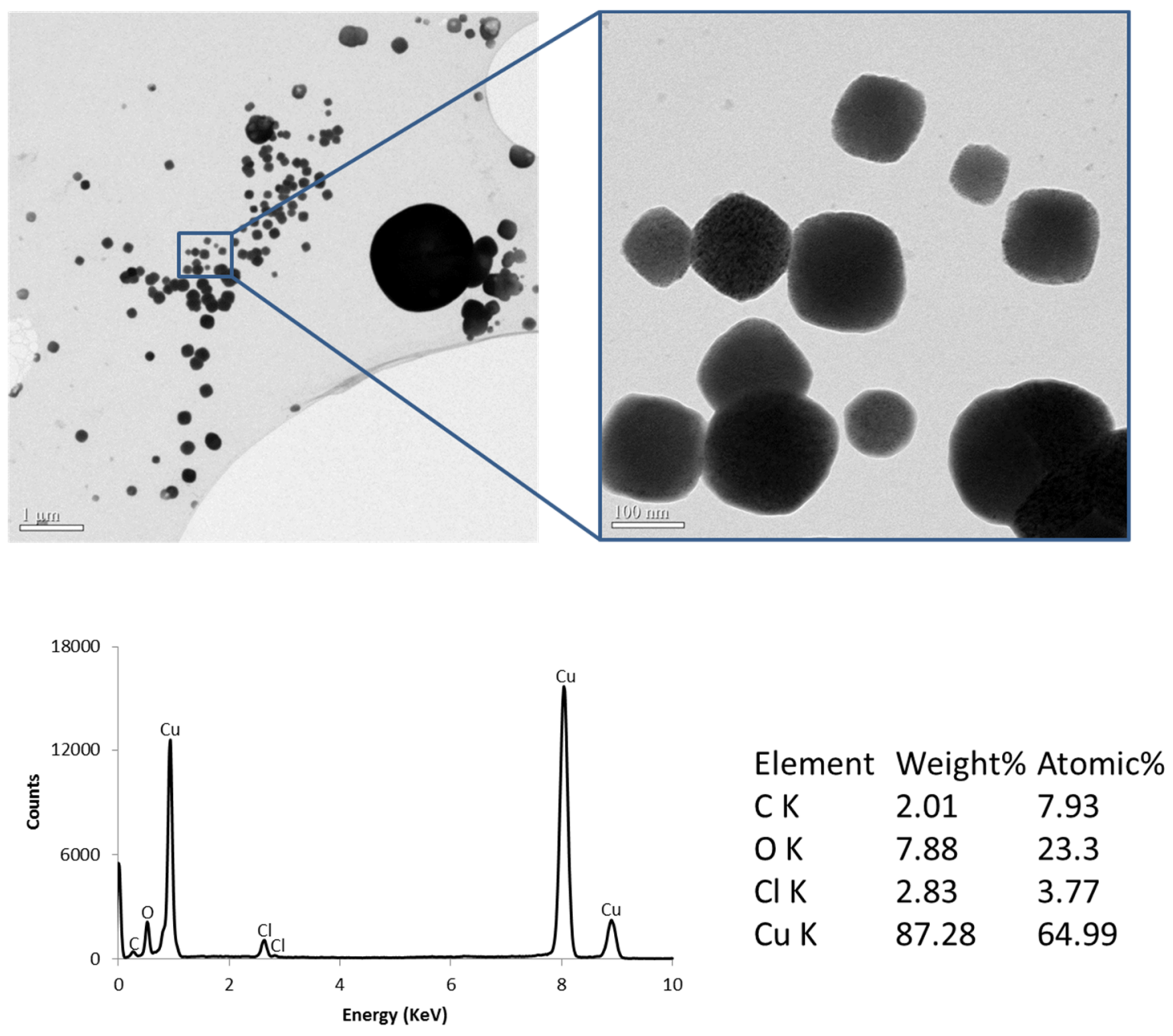

438

439

440

441

442
Figure 7. TEM micrographs and EDS analyses of particles detected in paint leachate. Leachate was collected from aluminum mini-bars submerged in seawater for $180 \mathrm{~d}$ 
443 A TEM micrograph of paint leachate showing the presence of particles is shown in Figure 6.

444 Particles in the leachates range in size from the nanoscale to a few microns. EDS analyses

445 confirmed that the particles were composed mainly of $\mathrm{Cu}$ and $\mathrm{O}$, most likely $\mathrm{Cu}_{2} \mathrm{O}$ as indicated

446 by XRD and XPS. The other elements detected by EDS $(\mathrm{C}, \mathrm{Cl})$ may be from the TEM grid

447 and/or aqueous media. The size of $\mathrm{Cu}_{2} \mathrm{O}$ particles is very important for the behavior of

448 antifouling paints as smaller particles significantly increase polishing/leaching (Kiil et al., 2002).

449 The environmental implications of these nanosized particles may also be different from that of

450 bulk materials. It has been shown that smaller sized $\mathrm{Cu}$ particles tend to dissolved faster, and

451 exhibit a higher toxic effect to aquatic organisms (Cai et al., 2005, Torres-Duarte et al., 2015).

452

453 The TEM with EDS data, which were obtained from samples submerged for $180 \mathrm{~d}$, further

454 proves that transformation of $\mathrm{Cu}_{2} \mathrm{O}$ in the antifouling paint is not very rapid. It is noteworthy that

455 the transformation rate of $\mathrm{Cu}_{2} \mathrm{O}$ particles in water may have been decreased due to saturation

456 under the study conditions. In addition, self-polishing paints are designed to slowly release their

457 biocides over time as water erodes the active polymer through hydrolysis (self-polishing effect)

458 (Kiil et al., 2002). As such, the particles detected after $180 \mathrm{~d}$ of paint exposure may have only

459 been released into water for a much shorter time.

460

461

462

$463 \quad$ 3.1.4 Effect of paint leachates on marine phytoplankton

464 The paint leachates obtained after submerging the mini-bars in seawater for $180 \mathrm{~d}$ were exposed

465 to I. galbana (a marine phytoplankton) in order to evaluate the potential effects of paint leachates 
466 in marine systems. Phytoplankton are primary producers in aquatic systems, and have long being 467 used to evaluate the environmental impacts of chemicals; phytoplankton are not a primary target 468 of the biocide in these paints. The leachates were diluted by a factor of 10 with pristine seawater 469 prior to exposure in order to reduce the concentrations of $\mathrm{Cu}$, and to simulate the concentration at 470 a distance away from the immediate surface. Each diluted leachate was exposed to

471 phytoplankton (at an initial density of $2 \times 10^{4}$ cells $/ \mathrm{mL}$ ) and growth inhibition over $5 \mathrm{~d}$ was used 472 as toxicity endpoint. Inhibition greater than $100 \%$ implies cell death.

473

474

475

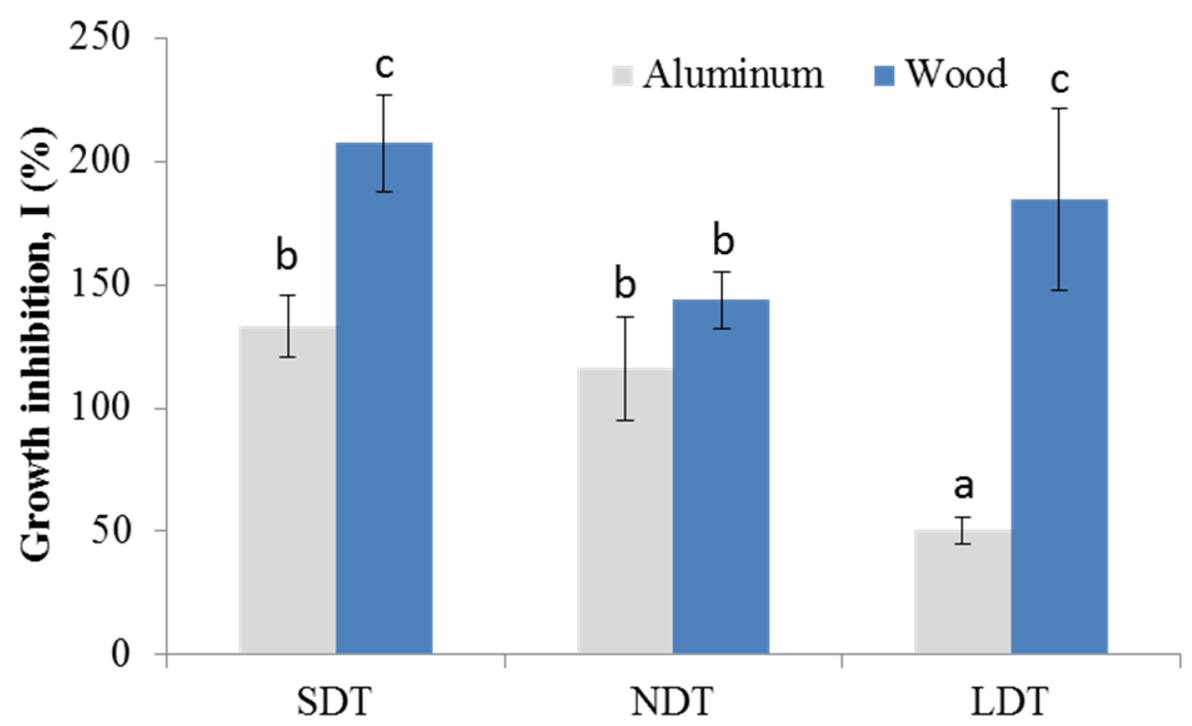

476 Figure 8. Growth inhibition of Isochrysis galbana after a $5 \mathrm{~d}$ exposure to paint leachates from

477 aluminum and wood mini-bars that were submerged in natural seawater for $180 \mathrm{~d}$. Mini-bars

478 were dried for $6 \mathrm{~h}$ (short drying time or SDT), $24 \mathrm{~h}$ (normal drying time or NDT), or 7d (long

479 drying time or LDT) prior to submerging them in seawater. Leachates were diluted by a factor of 48010 prior to exposure experiments. Mean values represented by distinct letters indicate significant 481 differences detected by one-way ANOVA followed by posthoc Tukey's test 
484 The paint leachates significantly inhibited the growth of I. galbana $(p<0.004)$ as shown in SI

485 Figure 7. Inhibition of growth was more severe when the phytoplankton were exposed to 486 leachates obtained from wood mini-bars (inhibition $=144-207 \%$ ) than those obtained from 487 aluminum mini-bars $(50-133 \%)$. This agrees with the trend of $\mathrm{Cu}$ concentration we detected in 488 the leachates, which was much higher in the wood mini-bar treatments. There was however no 489 clear correlation between percent inhibition and paint drying time. The other non-Cu biocides 490 present in the antifouling paint (e.g. ZnO, irgarol, etc.; Figure A.1), which we did not account for 491 in this study, may have complicated the toxicity pattern we observed (Dahl and Blanck, 1996).

\section{$494 \quad 4.1 \quad$ Conclusions and Environmental Implications}

$495 \mathrm{Cu}_{2} \mathrm{O}$ particles in commercial antifouling paints may be released into natural waters during use.

496 These released particles may include those that are nanoparticulate in size. The size of $\mathrm{Cu}_{2} \mathrm{O}$

497 particles is very important for the behavior of antifouling paints as smaller particles significantly

498 increase polishing/leaching (Kiil et al., 2002). The environmental implications of these nanosized 499 particles may also be different from that of bulk materials. It has been shown that smaller sized $500 \mathrm{Cu}$ particles tend to dissolve faster, and exhibit a higher toxic effect to aquatic organisms (Cai et 501 al., 2005, Torres-Duarte et al., 2015).

503 Release of biocides from surfaces painted with antifouling paints is controlled mainly by biocide 504 chemistry and environmental factors. However, release of biocides from antifouling paints may 
505 also be influenced by consumer behavior. As shown here, allowing painted hulls to dry for much

506 longer than recommended by the antifouling paint manufacturer may actually lead to additional

507 release of biocides into water. In addition, the type of surface on which antifouling coatings are

508 applied influences leaching of biocides, as materials with poor dimensional stability such as

509 wood may lead to additional leaching.

510

511 In addition to $\mathrm{pH}$, the dissolution and transformation of $\mathrm{Cu}_{2} \mathrm{O}$ particles in natural waters (where

$512 \mathrm{pH}$ range is quite narrow) is mainly driven by $\mathrm{Cl}^{-}$concentrations, which is abundant in marine

513 systems. However, although saturation is not likely in natural waters (at least, over time), the

514 transformation rate of $\mathrm{Cu}_{2} \mathrm{O}$ particles released into natural waters from antifouling paints will

515 decrease due to their encapsulation in resins. As a result, persistence of these potentially reactive

516 metals in the environment will increase, especially in freshwater systems. Although

517 environmental transformation may increasingly lead to complexation of $\mathrm{Cu}$ (and thus, reduced

518 bioavailability), the leachates may still pose significant threat to important ecological species.

520 This study investigated the physicochemical state of the biocides present in the leachate of a

$521 \mathrm{Cu}_{2} \mathrm{O}$-based antifouling paint. In summary, we found that:

522 - There were nanosized $\mathrm{Cu}_{2} \mathrm{O}$ particles in the commercial antifouling paint (in addition to 523 micronsized $\mathrm{Cu}_{2} \mathrm{O}$ ), although the paint was not labeled as nano-enabled. Nanosized $\mathrm{Cu}$

524 was also detected in the leachates of the commercial paint over 180 days;

525 - In natural waters, dissolution and leaching of $\mathrm{Cu}_{2} \mathrm{O}$ in the paint is driven mainly by $\mathrm{Cl}^{-}$

526 concentrations, leading to very high release of both dissolved and particulate $\mathrm{Cu}$ into

527 seawater compared to freshwater; 
- X-ray analyses showed that $\mathrm{Cu}_{2} \mathrm{O}$ particles in the antifouling paint is progressively transformed into $\mathrm{CuO}$ while dissolved $\mathrm{Cu}$ is precipitated as $\mathrm{CuCl}_{2}, \mathrm{Cu}(\mathrm{OH})_{2}$ or $\mathrm{CuCO}_{3}$. Despite the complexation, however, paint leachate was very toxic to marine phytoplankton; and

- Length of paint drying time and type of surface painted strongly influenced the amount of $\mathrm{Cu}$ released from antifouling paint into natural waters.

\section{Acknowledgement}

This material is based upon work supported by the National Science Foundation (NSF) and the Environmental Protection Agency (EPA) under Cooperative Agreement Number DBI 0830117. Any opinions, findings, and conclusions or recommendations expressed in this material are those of the authors and do not necessarily reflect the views of NSF or EPA. This work has not been subjected to EPA review and no official endorsement should be inferred. We thank the MRL Central Facilities, which are supported by the MRSEC Program of the NSF under Award No. DMR 1121053. The authors also thank Sage Davis for helping with mini-bar preparation, and Oluwaseun Sodimu and Edward Hadeler for their help with painting the mini-bars. We also appreciate Agilent Technologies for the Agilent Thought Leader Award given to A.A.K and the anonymous reviewers for their valuable contributions. 


\section{References}

550

551

552

553

554

555

556

557

558

559

560

561

562

563

564

565

566

567

568

569

570

571

572

573

574

575

576

577

578

579

580

581

582

583

584

585

586

587

588

589

590

591

592

593

Adeleye, A.S., Conway, J.R., Perez, T., Rutten, P.,Keller, A.A., 2014. Influence of Extracellular Polymeric Substances on the Long-Term Fate, Dissolution, and Speciation of Copper-Based Nanoparticles. Environ Sci Technol 48(21), 12561-12568.

Adeleye, A.S.,Keller, A.A., 2014. Long-term colloidal stability and metal leaching of single wall carbon nanotubes: Effect of temperature and extracellular polymeric substances. Water Research 49(0), 236-250.

Bielmyer-Fraser, G.K., Jarvis, T.A., Lenihan, H.S.,Miller, R.J., 2014. Cellular Partitioning of Nanoparticulate versus Dissolved Metals in Marine Phytoplankton. Environmental Science \& Technology 48(22), $13443-13450$.

Cai, S., Xia, X.,Xie, C., 2005. Research on Cu2+ transformations of $\mathrm{Cu}$ and its oxides particles with different sizes in the simulated uterine solution. Corrosion science 47(4), 1039-1047.

Comber, S.D.W., Gardner, M.J.,Boxall, A.B.A., 2002. Survey of four marine antifoulant constituents (copper, zinc, diuron and Irgarol 1051) in two UK estuaries. J Environ Monitor 4(3), 417-425.

Conway, J.R., Adeleye, A.S., Gardea-Torresdey, J.,Keller, A.A., 2015. Aggregation, Dissolution, and Transformation of Copper Nanoparticles in Natural Waters. Environmental Science \& Technology 49(5), 2749-2756.

Dahl, B.,Blanck, H., 1996. Toxic effects of the antifouling agent irgarol 1051 on periphyton communities in coastal water microcosms. Marine Pollution Bulletin 32(4), 342-350.

Dake, L.S., King, D.E.,Czanderna, A.W., 2000. Ion scattering and X-ray photoelectron spectroscopy of copper overlayers vacuum deposited onto mercaptohexadecanoic acid self-assembled monolayers. Solid State Sciences 2(8), 781-789.

Dzhurinskii, B., Gati, D., Sergushin, N., Nefedov, V.,Salyn, Y.V., 1975. Simple and coordination compounds. An X-ray photoelectron spectroscopic study of certain oxides. Russ. J. Inorg. Chem 20, 2307-2314.

Fairley, N.,Carrick, A., 2005. The Casa Cookbook-Part 1: Recipes for XPS Data Processing, Knutsford: Acolyte Science.

Ferry, J.D.,Carritt, D.E., 1946. Action of Antifouling Paints - Solubility and Rate of Solution of Cuprous Oxide in Sea Water. Ind Eng Chem 38(6), 612-617.

Hall, W.S., Bushong, S., Hall, L., Jr., Lenkevich, M.,Pinkney, A., 1988. Monitoring dissolved copper concentrations in Chesapeake Bay, U.S.A. Environmental Monitoring and Assessment 11(1), 3342.

Katranitsas, A., Castritsi-Catharios, J.,Persoone, G., 2003. The effects of a copper-based antifouling paint on mortality and enzymatic activity of a non-target marine organism. Marine Pollution Bulletin 46(11), 1491-1494.

Keller, A.A., Wang, H., Zhou, D., Lenihan, H.S., Cherr, G., Cardinale, B.J., Miller, R.,Ji, Z., 2010. Stability and Aggregation of Metal Oxide Nanoparticles in Natural Aqueous Matrices. Environmental Science \& Technology 44(6), 1962-1967.

Kiil, S., Weinell, C.E., Pedersen, M.S.,Dam-Johansen, K., 2001. Analysis of Self-Polishing Antifouling Paints Using Rotary Experiments and Mathematical Modeling. Ind. Eng. Chem. Res. 40(18), 3906-3920.

Kiil, S., Weinell, C.E., Pedersen, M.S.,Dam-Johansen, K., 2002. Mathematical Modelling of a Self-Polishing Antifouling Paint Exposed to Seawater: A Parameter Study. Chemical Engineering Research and Design 80(1), 45-52.

Miller, R.J., Bennett, S., Keller, A.A., Pease, S.,Lenihan, H.S., 2012. TiO2 nanoparticles are phototoxic to marine phytoplankton. PloS one 7(1), e30321. 
Moulder, J., Stickle, W., Sobol, P.E.,Bomben, K., 1995. Handbook of X-ray Photoelectron Spectroscopy. A Reference Book of Standard Spectra for Identification and Interpretation of Xps Data, Physical Electronics, Minnesota, USA.

Omae, I., 2003. General aspects of tin-free antifouling paints. Chemical Reviews 103(9), 3431-3448.

Parks, R., Donnier-Marechal, M., Frickers, P.E., Turner, A.,Readman, J.W., 2010. Antifouling biocides in discarded marine paint particles. Marine Pollution Bulletin 60(8), 1226-1230.

Shi, J., Abid, A.D., Kennedy, I.M., Hristova, K.R.,Silk, W.K., 2011. To duckweeds (Landoltia punctata), nanoparticulate copper oxide is more inhibitory than the soluble copper in the bulk solution. Environmental Pollution 159(5), 1277-1282.

Siddiqui, S., Goddard, R.H.,Bielmyer-Fraser, G.K., 2015. Comparative effects of dissolved copper and copper oxide nanoparticle exposure to the sea anemone, Exaiptasia pallida. Aquatic Toxicology 160, 205-213.

Singh, N.,Turner, A., 2009. Leaching of copper and zinc from spent antifouling paint particles. Environmental Pollution 157(2), 371-376.

Thit, A., Selck, H.,Bjerregaard, H.F., 2013. Toxicity of $\mathrm{CuO}$ nanoparticles and $\mathrm{Cu}$ ions to tight epithelial cells from Xenopus laevis (A6): Effects on proliferation, cell cycle progression and cell death. Toxicology in Vitro 27(5), 1596-1601.

Torres-Duarte, C., Adeleye, A.S., Pokhrel, S., Mädler, L., Keller, A.A.,Cherr, G.N., 2015. Developmental effects of two different copper oxide nanomaterials in sea urchin (Lytechinus pictus) embryos. Nanotoxicology, 1-9.

Turner, A., 2010. Marine pollution from antifouling paint particles. Marine Pollution Bulletin 60(2), 159171.

Valkirs, A.O., Seligman, P.F., Haslbeck, E.,Caso, J.S., 2003. Measurement of copper release rates from antifouling paint under laboratory and in situ conditions: implications for loading estimation to marine water bodies. Marine Pollution Bulletin 46(6), 763-779.

Vasquez, R.P., 1998. CuCO3 by XPS. Surface Science Spectra 5(4), 273-278.

Warnken, J., Dunn, R.J.K.,Teasdale, P.R., 2004. Investigation of recreational boats as a source of copper at anchorage sites using time-integrated diffusive gradients in thin film and sediment measurements. Marine Pollution Bulletin 49(9-10), 833-843.

Yamanaka, M., Yamanaka, K.,Itagaki, T., 2015. Automated, high sensitivity analysis of single nanoparticles using the Agilent 7900 ICP-MS with Single Nanoparticle Application Module, pp. 15, Agilent Technologies. 


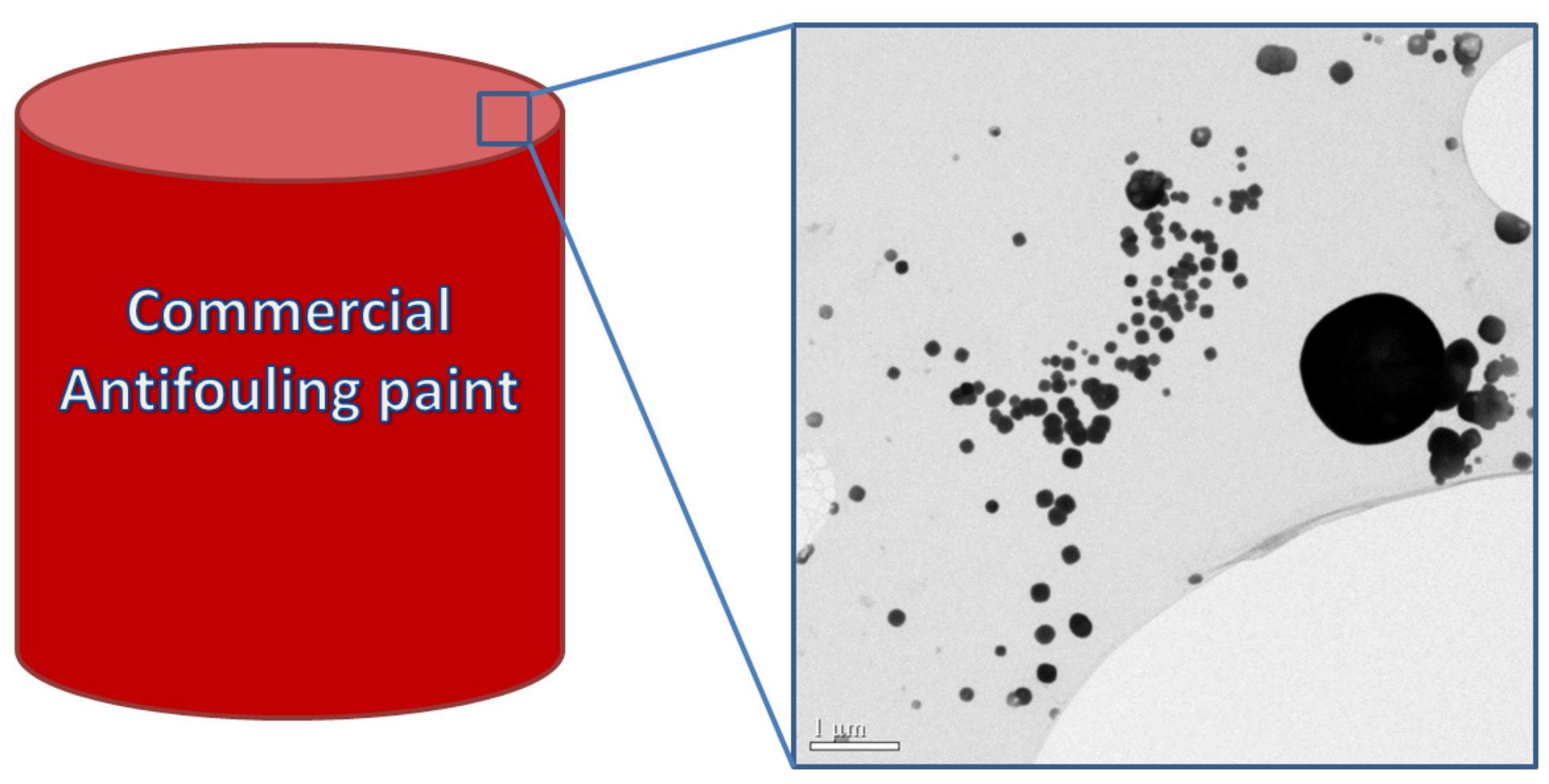

